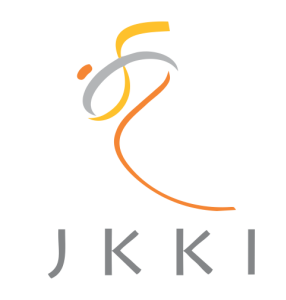

Jurnal Kedokteran dan Kesehatan Indonesia

Indonesian Journal of Medicine and Health

Journal homepage: https://journal.uii.ac.id/JKKI

SCIEMTIR EST BASIC VITAE

\title{
Challenges of malaria elimination in Indonesia
}

Novyan Lusiyana*1

${ }^{1}$ Department of Parasitology, Faculty of Medicine, Universitas Islam Indonesia, Yogyakarta, Indonesia

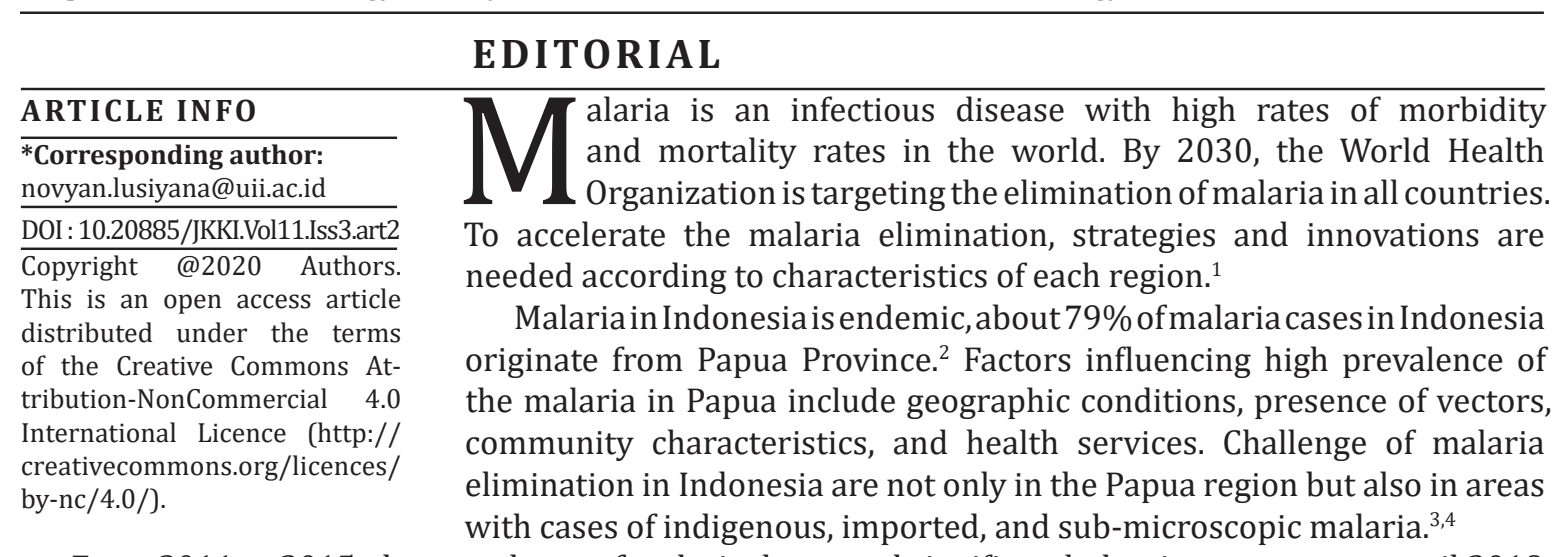

From 2011 to 2015, the prevalence of malaria decreased significantly, but it was stagnant until 2018. This condition shows that the program has not work optimally, especially to reduce the malaria cases, so involvement of various sectors is required. Cross-sector cooperation needs to be optimized by some program such as surveillance, vector control, monitoring, and program evaluation. ${ }^{4,5}$ Apart from routine malaria programs, innovation is also needed to support the existing programs. ${ }^{5,6}$

Progress of the elimination program in Indonesia in 2018 was that 285 districts/cities in Indonesia had received a malaria elimination certificate. ${ }^{2}$ Other regions are still working on the elimination of malaria. Several aspects related to a success of the malaria elimination program include presence of health workers in terms either in quality or quantity, availability of adequate malaria logistics, crosssector coordination, community involvement, well-functioning programs, and supportive local government policies. ${ }^{7}$ Through commitment and solid cooperation of various parties, eliminating malaria in Indonesia in 2030 will not be an arduous effort.

\section{REFERENCES}

1. WHO. Global technical strategy for malaria 2016-2030. World Health Organization. 2015. p. $1-35$.

2. Kemenkes RI. Situasi terkini perkembangan program pengendalian malaria di Indonesia tahun 2018. Jakarta; 2018.

3. Arwati H, Yotopranoto S, Rohmah EA, Syafruddin D. Submicroscopic malaria cases play role in local transmission in Trenggalek District, East Java Province, Indonesia. Malaria Journal. 2018;17(1).

4. Kemenkes RI. Brief Overview Situasi Malaria di Indonesia dan Beban Pada Ibu Hamil dan Anak. Jakarta; 2018. p. 1-12.

5. WHO. From malaria control to malaria elimination. WHO Library Cataloguing-in-Publication Data. Geneva; 2014. p. 53.

6. Hemingway J, Shretta R, Wells TNC, Bell D, Djimdé AA, Achee N, et al. Tools and strategies for malaria control and elimination: What do we need to achieve a grand convergence in malaria? 
PLoS Biology. 2016;14(3):e1002380.

7. Mobilala FD, Rantetampang AL, Sandjaja B, Pontiku A, Tingginehe R. Study of successful malaria elimination program at Teluk Bintuni District. International Journal of Science and Healthcare Research. 2019;4:232-43. 